\title{
Modified broken rice starch as fat substitute in sausages
}

\author{
Amido modificado de quirera de arroz como substituto de gordura em salsichas
}

\author{
Valéria Maria LIMBERGER ${ }^{1 \star}$, Fabrício Barros BRUM ${ }^{1}$, Luciana Dalpieve PATIAS ${ }^{1}$, \\ Ana Paula DANIEL ${ }^{1}$, Carine Gláucia COMARELA ${ }^{2}$, Tatiana EMANUELLI ${ }^{1,2}$, Leila Picolli da SILVA ${ }^{3}$
}

\begin{abstract}
The demand for low-fat beef products has led the food industry to use fat substitutes such as modified starch. About $14 \%$ of broken rice is generated during processing. Nevertheless, this by-product contains high levels of starch; being therefore, great raw material for fat substitution. This study evaluated the applicability of chemically and physically modified broken rice starch as fat substitute in sausages. Extruded and phosphorylated broken rice was used in low-fat sausage formulation. All low-fat sausages presented about $55 \%$ reduction in the fat content and around $28 \%$ reduction in the total caloric value. Fat replacement with phosphorylated and extruded broken rice starch increased the texture acceptability of low-fat sausages, when compared to low-fat sausages with no modified broken rice. Results suggest that modified broken rice can be used as fat substitute in sausage formulations, yielding lower caloric value products with acceptable sensory characteristics. Keywords: extrusion; phosphorylation; low-fat sausage; fat replacement; broken rice.
\end{abstract}

\section{Resumo}

A demanda por produtos cárneos de baixo teor de gordura tem conduzido a indústria a utilizar substitutos de gordura, entre estes está o amido modificado. Durante o beneficiamento do arroz, cerca de $14 \%$ de grãos quebrados são gerados. Porém, este subproduto tem altos níveis de amido, portanto, é uma excelente matéria-prima para a substituição de gordura. O estudo avaliou a aplicabilidade do amido de quirera de arroz modificado química e fisicamente como substitutos de gordura em salsicha. Quirera de arroz extrusada e fosforilada foi utilizada na formulação de salsicha de baixo teor de gordura. Todas as salsichas de gordura substituída apresentaram uma redução de 55\% no teor de gordura e de cerca de $28 \%$ do valor calórico total. A substituição por quirera de arroz extrusada e fosforilada aumentou a aceitabilidade da textura da salsicha quando comparada à salsicha sem quirera modificada. Os resultados sugerem que a quirera de arroz modificada pode ser utilizada como substituto de gordura em formulações de salsicha, desenvolvendo produtos de menor valor calórico com características sensoriais aceitáveis.

Palavras-chave: extrusão; fosforilação; salsicha light; substituto de gordura; quirera de arroz.

\section{Introduction}

Recently, the demand for low-fat beef products has increased due to consumers' concern about high fat diets, leading the food industry to develop light versions of their traditional products. Making low-fat products similar to the full fat ones is a difficult task (SIPAHIOGLU; ALVAREZ; SOLANO-LOPEZ, 1999). Several studies have shown significantly lower sensory scores for tenderness, juiciness, hardness and flavor in low-fat beef products (BREWER; MCKEITH; BRITT, 1992; BERRY, 1994; FREDERICK et al., 1994; MANSOUR; KHALIL, 1997). The use of a fat substitute improves the properties of reduced-fat foods (DRAKE; SWANSON, 1995). Among these substitutes we find modified starch, which is being used to replace fat in processed foods because of its water-binding properties (CHIN et al., 1998), imitating the softness conferred by fat. Modified starches have been proposed as fat substitutes in several foods, such as cheese (SIPAHIOGLU; ALVAREZ; SOLANO-LOPEZ, 1999), beef patties (KHALIL, 2000) and ice-cream (JIMENEZ-FLORES; KLIPFEL; TOBIAS, 1993; AIME et al., 2001). The rheological properties of starch may be improved or adapted to technological needs through physical (extrusion) or chemical (phosphorylation) modification (BRANEN; DAVIDSON; SALMINEN, 1990; KIM; HERMANSON; ERIKSSON, 1992; ELIASSON; GUDMUNDSSON, 1996; SIVAK; PREISS, 1998; ALVES; GROSSMANN; SILVA, 1999; STAHL et al., 2007). Starch phosphates prepared through chemical methods produce clear pastes of high consistency, good freeze/thaw stability, lower gelatinization temperatures and high swelling power and solubility (SIVAK; PREISS, 1998; SITOHY et al., 2000a; STAHL et al., 2007).

Extrusion is regarded as a sophisticated food process since it enables mixing, kneading, cooking and forming to take place continually by using a single machine and it is completed within

\footnotetext{
Received 18/2/2010

Accepted 5/6/2010 (004669)

Graduate Program on Food Science and Technology, Center of Rural Sciences, Federal University of Santa Maria - UFMS, Campus Camobi, CEP 97105-900,

Santa Maria, RS, Brazil, e-mail vlimberger@yahoo.com.br

2 Integrated Center of Laboratory Analysis Development - NIDAL, Department of Food Science and Technology, Center of Rural Sciences,

Federal University of Santa Maria - UFMS, Santa Maria, RS, Brazil

${ }^{3}$ Department of Zootechnical, Center of Rural Sciences, Federal University of Santa Maria - UFMS, Santa Maria, RS, Brazil

${ }^{*}$ Corresponding author
} 
a short period of time (MILLER, 1988). Extrusion promotes a high physical modification in granular structure, increasing water absorption and retention (LIMBERGER et al., 2008).

Rice has, on average, $88 \%$ of starch (VARAVINIT et al., 2003) and Brazil is the most important producer of this cereal outside the Asiatic continent, occupying the $7^{\text {th }}$ worldwide position (COMPANHIA..., 2009). About $14 \%$ of broken rice is generated during processing - reaching $60 \%$ in the case of dry grain. This represents a great economic loss for the rice industry, because the commercial value of broken rice is only one-fifth of the that obtained in the commercialization of whole grain.

Limberger et al. (2008) evaluated the efficiency of chemical (phosphorylation) and physical (extrusion) modifications of broken rice starch. Both phosphorylation and extrusion increased cold water binding capacity, swelling power, and solubility. Extruded and phosphorylated pastes were stable under refrigeration, but only extruded paste was stable when submitted to freezing. Phosphorylated paste presented the lowest viscosity and the highest stability during heating - while the extruded gelatinized without heating - but showed higher losses during heating.

In order to take advantage of broken rice, it was evaluated as a source of starch for chemical (phosphorylation) or physical (extrusion) modification, and the modified starches obtained were assessed as fat substitutes in sausages.

\section{Materials and methods}

Broken rice with no dirt or black points was donated by two local mills. The chemical composition of broken rice in dry basis was $8.13 \%$ protein, $1.15 \%$ fat, $0.45 \%$ ash, $2.13 \%$ fiber and $76.35 \%$ starch (with $22.5 \%$ amylose content).

\subsection{Extrusion}

A single-screw extruder was employed for this study. It was of rising compression, with short rolls and without-end-screw, operating at $112 \pm 1{ }^{\circ} \mathrm{C}$ temperature and $480 \mathrm{rpm}$ rotation. Broken rice was conditioned to $14 \%$ moisture before being introduced in an extrusion chamber. The temperature of dough in the extrusion chamber was $112 \pm 1{ }^{\circ} \mathrm{C}$ immediately after the orifice passage. The extruded sample was pulverized and stored in hermetically closed containers, under refrigeration, at the moment of being used.

\subsection{Phosphorylation}

The broken rice starch phosphate was obtained using sodium tripolyphosphate ( $0.126 \mathrm{~g} . \mathrm{g}^{-1}$ of starch) as described by Paschall (1964), with a minor change in the phosphorylation time. The samples were heated at $150-155^{\circ} \mathrm{C}$ for 40 minutes. The amount of phosphorus bound after phosphorylation was determined before and after dialysis of 5\% starch slurry (w/v in water) as described by Sitohy et al. (2000a). The phosphorus content was determined as described by Tedesco, Gianello and Bohnen (1996) at $805 \mathrm{~nm}$, after digestion in sulfuric acid. Milled broken rice was used in the phosphorylation process.

\subsection{Sausage formulations}

The sausage formulation consisted of (w/w) 57\% meat, 2.7\% common salt, $0.3 \%$ phosphate, $0.6 \%$ white pepper, $0.045 \%$ garlic, $0.06 \%$ glutamate, $16.4 \%$ water, and $0.54 \%$ sausage condiment. $20 \%$ fat (T20C, control) or $5 \%$ fat $+2 \%$ cassava starch (T5C) or $5 \%$ fat $+2 \%$ extruded broken rice (T5E) or $5 \%$ fat $+2 \%$ cassava starch $+2 \%$ extruded broken rice (T5EC) or $5 \%$ fat + $2 \%$ phosphorylated broken rice (T5P) or $5 \%$ fat $+2 \%$ cassava starch $+2 \%$ phosphorylated broken rice (T5PC) were added to this mixture. Cassava starch, an element common in sausage formulations in Brazil, was used in the control groups. Extruded and phosphorylated broken rice were added as water paste $(10 \%$, $\mathrm{w} / \mathrm{w})$. The meat used in the sausage formulation was half beef and half pork, both without fat.

The formulations were stored at $6{ }^{\circ} \mathrm{C}$ for 24 hours until sensory analysis. For fat, protein and ash analysis, sausages were finely ground employing ultra Turrax equipment (model T18 basic, IKA).

\subsection{Chemical composition}

Moisture (method 950.46), ash (method 923.03), and protein (method 960.52, conversion factor: 6.25) contents were determined according to AOAC (ASSOCIATION..., 1995). Fat was measured as described by Bligh and Dyer (1959), with chloroform addition, which separates the fat in the lower layer. An aliquot of the lower layer was held at $105 \pm 2{ }^{\circ} \mathrm{C}$ for two hours until the solvent evaporated and the fat was measured by residual weight. The caloric value was calculated using: $\mathrm{fat}=9$ calories, carbohydrates $=4$ calories and protein $=4$ calories (ASSOCIATION..., 1995).

\subsection{Sensory analysis}

Sausages were evaluated through Hedonic scale test, according to the Brazilian Technical Standards Association (ASSOCIAÇÃO..., 1993, 1998). An untrained panel made up of 35 panelists was selected from students and staff members of the Department of Food Science and Technology, Federal University of Santa Maria. They evaluated texture using a seven-point hedonic scale: disliked extremely (1), disliked very much (2), dislike (3), indifferent (4), liked (5), like very much (6), liked extremely (7). Before the sensory analysis, the samples were heated to $80^{\circ} \mathrm{C}$ and served immediately.

\subsection{Statistical analysis}

The experiment was conducted in a completely randomized design, in three lots and in triplicate. The data was analyzed by one-way analysis of variance (ANOVA) and compared through the F-test. In significant models, the means were compared using the post-hoc test of Tukey's multiple range. The data were analyzed using the SPSS ${ }^{\bullet} 8.0$ software package (STATISTICAL..., 1997). Differences were considered to be significant when $\mathrm{p}<0.05$. 


\section{Results and discussion}

\subsection{Phosphorus content}

Phosphorus content significantly increased after phosphorylation (Table 1). Dialysis reduced the phosphorus content, indicating the need of this procedure to remove the unbound phosphorus after phosphorylation. For this reason, the substitution degree of rice starch phosphate was calculated based on the content of phosphorus after dialysis. This value was similar to those previously reported for corn starch after phosphorylation under similar conditions (PASCHALL, 1964; SITOHY et al., 2000b; STAHL et al., 2007). Codex Alimentarius (2009) establishes a limit of $0.4 \%$ residual phosphate for phosphorylated rice starches. Thus, the broken rice starch phosphate obtained in the present study is suitable for food use.

\subsection{Chemical composition}

All low-fat sausages (T5C, T5E, T5P, T5EC, T5PC) presented reduction of about $55 \%$ in the fat content when compared to control (T20C) full-fat sausages. This reduction is similar to that reported by Candogan and Kolsarici (2003) for low-fat sausages (Table 2). All low-fat sausages had significantly higher protein content when compared to control full-fat sausages (Table 2). Similar results were reported by Cofrades, Hughes and Troy (2000). The increased protein content seemed to play a major role in the increased firmness of low-fat sausages (PIETRASIK, 1999). When the fat content is reduced by increasing the water content and keeping the amount of protein constant, low-fat products with lower hardness level are obtained (GREGG et al., 1993).

Moisture was higher in all the samples of low-fat sausages than in the control full-fat sausages (Table 2). Pietrasik (1999) evaluated potato modified starch as a fat substitute in sausages

Table 1. Phosphorus (P) content (\%) and substitution degree of native and phosphorylated broken rice before and after dialysis process.

\begin{tabular}{lccc}
\hline $\begin{array}{c}\text { Broken } \\
\text { rice }\end{array}$ & $\begin{array}{c}\text { Before } \\
\text { dialysis }\end{array}$ & $\begin{array}{c}\text { After } \\
\text { dialysis }\end{array}$ & $\begin{array}{c}\text { Substitution degree } \\
\text { (after dialysis process) }\end{array}$ \\
\hline Native & $0.104 \pm 0.006^{\mathrm{b}}$ & $0.063 \pm 0.003^{\mathrm{b}}$ & $0.003 \pm 0.0003^{\mathrm{b}}$ \\
Phosphorylated & $0.915 \pm 0.015^{\mathrm{a}}$ & $0.310 \pm 0.004^{\mathrm{a}}$ & $0.024 \pm 0.0020^{\mathrm{a}}$ \\
\hline
\end{tabular}

Values followed by distinct letters within the column are different by $\mathrm{T}$ test $(\mathrm{p}<0.05)$ $(n=3)$. and also observed the behavior of increased moisture along with lower fat levels. Khalil (2000) also observed an increase in the moisture of beef patties as the replacement degree of modified corn starch increased. The increase in moisture in sausage containing modified starch may be attributed to the high water absorption capacity of starch (SIPAHIOGLU; ALVAREZ; SOLANO-LOPEZ, 1999). The reduction in the total caloric value was around $28 \%$ in the low fat sausages formulated with modified broken rice starch as fat substitute when compared to the control full-fat sausage.

\subsection{Sensory analysis}

Fat replacement with phosphorylated and/or extruded broken rice starch increased the texture acceptability of low-fat sausages when compared to low-fat sausages without modified broken rice (Figure 1).

There was no significant difference in texture acceptability between sausages formulated with broken rice modified by extrusion or phosphorylation, which proves the efficacy of both fat substitutes (Figure 1). Likewise, the cassava starch addition did not significantly modify the samples acceptability.

Khalil (2000) observed that modified corn starch improved sensory properties of low-fat beef patties; with the exception of flavor intensity, which was slightly different.

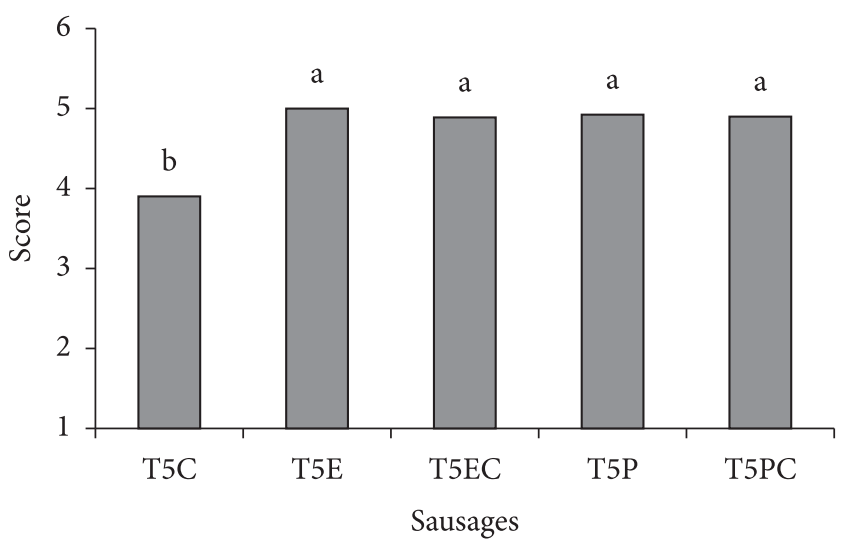

Figure 1. Texture scores of sausages formulated with physically and chemically modified broken rice. Columns with distinct letters are different by Tukey's test $(\mathrm{p}<0.05)(\mathrm{n}=35)$.

Table 2. Fat, moisture, protein, ash (\%) and caloric value (kcal.100 $\left.\mathrm{g}^{-1}\right)$ of sausages elaborated with extruded and phosphorylated broken rice.

\begin{tabular}{|c|c|c|c|c|c|}
\hline Samples & Fat & Moisture & Protein & Ash & Caloric value \\
\hline T20C & $13.88 \pm 0.04^{\mathrm{a}}$ & $67.72 \pm 0.21^{b}$ & $16.33 \pm 0.09^{b}$ & $1.52 \pm 0.05^{\mathrm{d}}$ & 198.24 \\
\hline $\mathrm{T} 5 \mathrm{C}$ & $6.45 \pm 0.35^{b c}$ & $70.03 \pm 0.27^{\mathrm{a}}$ & $19.05 \pm 0.24^{\mathrm{a}}$ & $1.74 \pm 0.03^{\mathrm{b}}$ & 142.29 \\
\hline $\mathrm{T} 5 \mathrm{E}$ & $6.01 \pm 0.77^{b c}$ & $70.08 \pm 0.81^{\mathrm{a}}$ & $18.46 \pm 0.32^{\mathrm{a}}$ & $1.70 \pm 0.03^{b c}$ & 135.93 \\
\hline T5P & $5.64 \pm 0.43^{c}$ & $70.37 \pm 0.30^{\mathrm{a}}$ & $18.74 \pm 0.39^{\mathrm{a}}$ & $1.92 \pm 0.10^{\mathrm{a}}$ & 133.72 \\
\hline T5EC & $7.12 \pm 0.36^{\mathrm{b}}$ & $70.01 \pm 0.20^{\mathrm{a}}$ & $19.22 \pm 0.74^{\mathrm{a}}$ & $1.63 \pm 0.01^{\mathrm{bcd}}$ & 156.96 \\
\hline T5PC & $6.19 \pm 0.37^{b c}$ & $71.81 \pm 0.21^{\mathrm{a}}$ & $19.05 \pm 0.61^{\mathrm{a}}$ & $1.55 \pm 0.08^{\mathrm{cd}}$ & 147.91 \\
\hline
\end{tabular}

Values that have no common superscript letter within the column are different by Tukey's test $(\mathrm{p}<0.05)(\mathrm{n}=3)$. 


\section{Conclusions}

Broken rice modified by extrusion or phosphorylation can be used as fat substitutes in sausage formulations, yielding lower caloric value products with acceptable sensory characteristics.

\section{References}

AIME, D. B. et al. Textural analysis of fat reduced vanilla ice cream products. Food Research International, v. 34, p. 237-246, 2001. http://dx.doi.org/10.1016/S0963-9969(00)00160-5

ALVES, R. M. L.; GROSSMANN, M. V. E.; SILVA, R. S. S. F. Gelling properties of extruded yam (Dioscores alata) starch. Food Chemistry, v. 67, p. 123-127, 1999. http://dx.doi.org/10.1016/ S0308-8146(99)00064-3

ASSOCIAÇÃO BRASILEIRA DE NORMAS TÉCNICAS - ABNT. NBR 12994: Métodos de análise sensorial dos alimentos e bebidas. São Paulo: ABNT, 1993. 2 p.

ASSOCIAÇÃO BRASILEIRA DE NORMAS TÉCNICAS - ABNT. NBR 14141: Escalas utilizadas em análise sensorial de alimentos e bebidas. São Paulo: ABNT, 1998. 3 p.

ASSOCIATION OF THE OFFICIAL ANALYSIS CHEMISTS - AOAC. Official methods of Analysis of the Association of the Official Analysis Chemists. 16th ed. Arlington: AOAC, 1995.

BERRY, B. W. Fat level, high temperature cooking and degree of doneness affect sensory, chemical and physical properties of beef patties. Journal of Food Science, v. 59, p. 10-14, 1994. http://dx.doi. org/10.1111/j.1365-2621.1994.tb06885.x

BLIGH, E. C.; DYER, W. J. A rapid method of total lipid. Extraction and purification. Canadian Journal of Biochemistry and Physiology, v. 37, p. 911-917, 1959. http://dx.doi.org/10.1139/o59-099

BRANEN, A. L.; DAVIDSON, P. M.; SALMINEN, S. Food Additives. New York, 1990. p. 405-406. (p. Series Food Science and Technology).

BREWER, M. S.; MCKEITH, F. K.; BRITT, K. Fat, soy and carrageen in effects on sensory and physical characteristics of ground beef patties. Journal of Food Science, v. 57, p. 1051-1052, 1992. http:// dx.doi.org/10.1111/j.1365-2621.1992.tb11259.x

CANDOGAN, K.; KOLSARICI, N. Store stability of low-fat beef frankfurters formulated with carrageen or carrageen with pectin. Meat Science, v. 64, p. 207-214, 2003. http://dx.doi.org/10.1016/ S0309-1740(02)00182-1

CHIN, K. B. et al. Low-fat bologna in a model system with varying types and levels of konjac blends. Journal of Food Science, v. 63, p. 808812, 1998. http://dx.doi.org/10.1111/j.1365-2621.1998.tb17905.x

COFRADES, S.; HUGHES, E.; TROY, D.J. Effects of oat fiber and carrageenan on the texture of frankfurters formulated with low and high fat. European Food Research and Technology, v. 211, p. 19-26, 2000. http://dx.doi.org/10.1007/s002170050583

CODEX ALIMENTARIUS. Disponível em: <http://www. codexalimentarius.net>. Acesso em: 20 jun. 2009.

COMPANHIA NACIONAL DE ABASTECIMENTO - CONAB. Disponível em: <http://www.conab.gov.br>. Acesso em: $20 \mathrm{dez}$. 2009.

DRAKE, M. A.; SWANSON, B. G. Reduced and low-fat cheese technology: a review. Trends in Food Science, v. 6, p. 366-369, 1995. PMid:21299575. http://dx.doi.org/10.1016/S0924-2244(00)89192-X

ELIASSON, A. C.; GUDMUNDSSON, M. Starch: physicochemical and functional aspects. In: Carbohydrates in Food. New York: Marcel Dekker, 1996. p. 431-503.
FREDERICK, T.L. et al. Characteristics of $95 \%$ lean beefGerman sausages varying in phosphate and added water. Journal of Food Science, v. 59, p. 453-455, 1994. http://dx.doi.org/10.1111/j.1365-2621.1994. tb05537.x

GREGG, L. L. et al. Low-fat, high added water bologna from massaged, minced batter. Journal of Food Science, v. 58, p. 259-264, 1993. http://dx.doi.org/10.1111/j.1365-2621.1993.tb04251.x

JIMENEZ-FLORES, R.; KLIPFEL, N. J.; TOBIAS, J. Ice cream and frozen desserts. In: HUI, Y. H. (Ed.). Dairy Science and Technology Handbook. New York: VCH Publishers, 1993. v. 2: Product Manufacturing. p. 57-15.

KHALIL, A. H. Quality characteristics of low-fat beef patties formulated with modified corn starch and water. Food Chemistry, v. 68 , p. 61-68, 2000. http://dx.doi.org/10.1016/S0308-8146(99)00156-9

KIM, H. R.; HERMANSON, A. M.; ERIKSSON, C. E. Structural characteristics of hydroxypropyl potato starch granules depending on their molar substitution. Starch/Stärke, v. 42, p. 418-423, 1992.

LIMBERGER, V. M. et al. Modificação Química e Física do Amido de Quirera de Arroz para aproveitamento na Indústria de Alimentos. Química Nova, v. 31, p. 84-88, 2008.

MANSOUR, E. H.; KHALIL, A. H. Characteristics of low-fat beef burger as influenced by various types of wheat fibers. Food Research International, v. 30, p. 199-205, 1997. http://dx.doi.org/10.1016/ S0963-9969(97)00043-4

MILLER, R. C. Continuous cooking of breakfast cereal. Cereal Foods World, v. 33, p. 284-291, 1988.

PASCHALL, E. F. Phosphation with inorganic phosphate salts. In: WHISTLER, R. L. (Ed.). Methods in carbohydrate chemistry. New York: Academic Press, 1964. p. 294-296.

PIETRASIK, Z. Effect of content of protein, fat and modified starch on binding textural characteristics, and colour of comminuted scalded sausages. Meat Science, v. 51, p. 17-25, 1999. http://dx.doi. org/10.1016/S0309-1740(98)00068-0

SIPAHIOGLU, O.; ALVAREZ, V. B.; SOLANO-LOPEZ, C. Structure, physicochemical and sensory properties of feta cheese made with tapioca starch and lecithin as fat mimetics. International Dairy Journal, v. 9, p. 783-789, 1999. http://dx.doi.org/10.1016/S09586946(99)00150-8

SITOHY, M. Z. et al. the conditions for starch dry phosphorylation with sodium mono- and dihydrogen orthophosphate under heat and vacuum. Starch/Stärke, v. 52, p. 95-100, 2000a.

SITOHY, M. Z. et al.. Physicochemical properties of different types of starch phosphate monoesters. Starch/Stärke, v. 52, p. 101-105, 2000b.

SIVAK, M. N.; PREISS, J. Industrial Applications of starch. In: SIVAK, M. N.; PREISS, J. Advances in Food Nutrition Research. Academic Press, 1998. v. 41: Starch: basic science to biotechnology. p. 163-170.

STATISTICAL PACKAGE FOR THE SOCIAL SCIENCES - SPSS INCORPORATION. SPSS for Windows. Statistical Package for the Social Sciences. Release 8.0. Chicago: SPSS Inc., 1997.

STAHL, J. A. et al. Physicochemical properties of Pinhão (Araucaria angustifolia, Bert, O. Ktze) starch phosphates. LebensmittelWissenschaft \& Technologie, v. 40, p. 1206-1214, 2007.

TEDESCO, M. J.; GIANELLO, C.; BOHNEN, H. Análises de Solos, Plantas e outros Materiais. 2. ed. Porto Alegre: Departamento de Solos da University of Rio Grande do Sul, 1996. 174 p. (Boletim Técnico, n. 5).

VARAVINIT, S. et al. Effect of Amylose Content on Gelatinization, Retrogradation and Pasting Properties of Flours from Different Cultivar of Thai Rice. Starch/stärke, v. 55, p. 410-415, 2003. 